\title{
冬季の根域加温はインパチェンスの生育促進に効果的である
}

\author{
村松嘉幸・窪田＼cjkstart聡*・腰岡政二 \\ 日本大学生物資源科学部２52-0880 神奈川県藤沢市亀井野
}

\section{Root-zone Heating during Winter Season is Effective to Promote Growth of Impatiens walleriana Hook. f.}

\author{
Yoshiyuki Muramatsu, Satoshi Kubota* and Masaji Koshioka \\ Nihon University, Collage of Bioresource Sciences, Kameino, Fujisawa, Kanagawa 252-0880
}

\begin{abstract}
Impatiens (Impatiens walleriana Hook. f.), whose cultivation requires heating in a greenhouse during the winter season, was used in this experiment to investigate the effects of root-zone heating on growth, flowering, and energy consumption. Four combinations of minimum air temperatures and root-zone temperatures: $8^{\circ} \mathrm{C} /$ non-heating, $13^{\circ} \mathrm{C} /$ non-heating, $8^{\circ} \mathrm{C} / 13^{\circ} \mathrm{C}$, and $8^{\circ} \mathrm{C} / 18^{\circ} \mathrm{C}$, were set, respectively, and the Impatiens plants were cultivated from February 1 to April 22, 2014 in a greenhouse. The number of leaves, leaf area, and dry weight of the top increased with rising average root-zone temperatures, and there was a close relationship between growth and the average root-zone temperature. The flowering season was about 10 days earlier at $8^{\circ} \mathrm{C} / 13^{\circ} \mathrm{C}$ and $8^{\circ} \mathrm{C} / 18^{\circ} \mathrm{C}$ than that at $13^{\circ} \mathrm{C} /$ non-heating. Energy consumption at $8^{\circ} \mathrm{C} / 18^{\circ} \mathrm{C}$, when growth and flowering were the most accelerated, was reduced by about $32 \%$ compared with that at $13^{\circ} \mathrm{C} /$ non-heating.
\end{abstract}

Key Words : energy-saving, local heating, porous pot, root-zone temperature

キーワード : 根域温度, 局所加温, 省エネルギー, 多孔質鉢

\section{緒言}

非耐寒性 1 年草を春に早期出荷するためには, 冬季から 播種・育苗が必要であり, 温室などでの加温栽培が必須で ある，農林水産省（2008）は施設園芸省エネルギー型栽培 技術を開発するらえで, 果菜類・花き類などに扣いて $30 \%$ 以上の省エネルギー効果のある局所加温技術の開発を 求めている. 森山ら (2011) は通常 $12^{\circ} \mathrm{C}$ で管理するナス の促成栽培に打いて, 株元加温によりハウス内の温度を $10^{\circ} \mathrm{C}$ に下げても慣行栽培と同等の収量が確保され, 灯油 消費量を $31 \%$ 削減できることを明らかにした，神奈川県 下に拈いて，バラは最低気温を $18^{\circ} \mathrm{C}$ に保ち栽培するが, $15^{\circ} \mathrm{C}$ に下げても株元加温を併用すると高い生産性が確保 でき，慣行栽培と比べて温室への投入暖房熱量は約 $20 \%$ 削減され，採花本数当たりのA重油使用量も約 $40 \%$ 削減 できる（神奈川県農業技術センター，2012）。鉢物栽培で は数種の観葉植物に执いて温室に設置したチャンバー内を 電熱線で加温することにより, 温室全体を $20^{\circ} \mathrm{C} て ゙$ 管理し た場合と同等の生育を示し，暖房コストを約 50\%削減で きる(新井ら，2009）。このよらに, 農林水産省の開発目 標をクリアする省エネルギー型の局所加温技術の開発が近

2016 年 10 月 25 日 受付. 2016 年 12 月 18 日 受理.

* Corresponding author. E-mail: kubota.satoshi@nihon-u.ac.jp
年進んでいる.

窪田ら（2011）は，排水孔のない多孔質鉢にパンジーを 植え込み, これを底面給水装置の給水槽に打いて, 生育を 調査したところ，頭上灌水やマット給水よりも生育が促進 され，多孔質鉢は根域温度などの環境条件を調節する根域 環境制御システム（RECS）の水供給装置として利用可能 であることを明らかにした。ささらに，RECSを利用しバー ベナとゼラニウムの生育・開花に及ぼす根域加温の影響に ついて検討したところ，根域加温によって地上部の成長と 開花が促進された（窪田ら，2013）。このため，気温を標 準的な栽培温度よりも低く管理し，RECSを用いて根域を 加温することにより，全体の投入エネルギー量を低減でき る可能性が示唆された。 しかし， RECSにおける投入エネ ルギー量扣よび根域温度と生育・開花との関係については 明らかになっていない。

インパチェンスは春から秋にかけての花壇苗としての需 要が大きい. 春の早期出荷のためには冬季に播種し育苗す る必要があるが, インパチェンスの生育適温は $20 \sim 25^{\circ} \mathrm{C}$ であり, $15^{\circ} \mathrm{C}$ 以下で花付きの減少や生育が劣り, $5^{\circ} \mathrm{C}$ 以 下では生育が停止する（西村, 1994)。従って, 冬季栽培 には $15^{\circ} \mathrm{C}$ 以上に加温することが望ましいが，生産者に よっては $13^{\circ} \mathrm{C}$ 程度に最低気温を抑え, 経費の節減を図っ ている.

そこで本研究では，RECSの実用化を目指した開発の一 
環として，小規模なプロトタイプによる根域加温が, どの 程度の省エネルギー性を持つかを評価するために，冬季の インパチェンス栽培に沶いて，投入エネルギー量と生育・ 開花との関係を調查し, 根域温度と地上部の生育との関連 性について解析した.

\section{材料および方法}

供試材料はインパチェンス (Impatiens walleriana Hook. f.) ‘インプレザ レッド’を用いた。本葉が $3 \sim 6$ 枚のセル 成型苗を 2014 年 1 月 31 日に培養土（赤玉：黒土=1:1）を 充填した排水孔のない 4 号素焼鉢（多孔質鉢）飞定植した. 肥料はマグアンプ $\mathrm{K}\left(\mathrm{N}: \mathrm{P}_{2} \mathrm{O}_{5}: \mathrm{K}_{2} \mathrm{O}: \mathrm{MgO}=6: 40: 6: 15\right.$, (株)八イポネックスジャパン)を基肥として1鉢当たり $3 \mathrm{~g}$ を施用した。 追肥は施用しなかった. 実験区は最低気 温を $8^{\circ} \mathrm{C}$ と, 根域温度を無加温 $\left(8^{\circ} \mathrm{C} /\right.$ 無加温区 $), 13^{\circ} \mathrm{C}$ $\left(8^{\circ} \mathrm{C} / 13^{\circ} \mathrm{C}\right.$ 区 $)$ 打よび $18^{\circ} \mathrm{C}\left(8^{\circ} \mathrm{C} / 18^{\circ} \mathrm{C}\right.$ 区 $)$ と最低気温を $13^{\circ} \mathrm{C}$ と, 根域温度を無加温. $\left(13^{\circ} \mathrm{C} /\right.$ 無加温区 $)$ とした 計 4 区とした，各区 10 株の 5 反復とした。実験は神奈川 県藤沢市の日本大学生物資源科学部農場のガラス温室で 行った.

RECSは村松ら（2015）と同一のものを使用した. RECS 用のプールは白色発泡スチロール製の EK 水槽 I 型（幅 $324 \mathrm{~cm}$, 高さ $16 \mathrm{~cm}$, 奥行き $129 \mathrm{~cm}$, カネコ種苗(株)）を用 い, これを高さ約 $70 \mathrm{~cm}$ の栽培ベンチ上に置き, プールの 内側を防水シートで被覆した。 これに $4 \mathrm{~cm}$ 間隔で直径 $12.5 \mathrm{~cm}$ の穴を横 5 列, 縦 7 列開忷た断熱材 $($ 幅 $90 \mathrm{~cm}$, 高 さ $2.5 \mathrm{~cm}$, 奥行き $120 \mathrm{~cm}$, スタイロフォーム $\mathrm{IB}$, ダウ化工 (株)）を 3 枚乗せ，その穴に植物を植えた 4 号の多孔質鉢 をはめ込んだ. プール内の水は排水口を通して栽培ベン チの下に設置した給水槽（幅 $50 \mathrm{~cm}$, 高さ $35 \mathrm{~cm}$, 奥行き $40 \mathrm{~cm}$ ) に集め, この中に $500 \mathrm{~W}$ の水中ヒーター（パワー セーフプロ 500, (株)マルカン) を設置した。 給水槽から 給水ポンプ（コンパクトポンプ 300 , エーハイムジャパン (株)）で水をクーラー（LX-300ESB，(株)イワキ）に通し た後,プールに汲久上げ循環させた。 プールの水深は常に $4 \mathrm{~cm}$ になるように調節した。なお，本実験ではクーラー は稼㗢させなかった。

この栽培ベンチを直径 $16 \mathrm{~mm}$ の鉄パイプで作製した保 温枠（幅 $350 \mathrm{~cm}$, 高さ $240 \mathrm{~cm}$, 奥行き $160 \mathrm{~cm}$ ) で囲み, 被 覆材（サニーユート, 宇部日東化成(株)）で二重被覆し, 4 月 5 日以降は気温の上昇に伴って被覆材を 1 枚にした.

気温調節には, 各区 1 台ずつ $1000 \mathrm{~W} の$ 電気温風機 (SF-1008A, 総和工業(株) ) を用いた. 電気温風機は常時 送風するようにし, 保温枠内の空気が循環するようにし た. 設定温度を下回った場合にヒーター部の電源が入る設 定とした．最高気温の制御は特に行わなかった． $8^{\circ} \mathrm{C} /$ $13^{\circ} \mathrm{C}$ 区拈よび $8^{\circ} \mathrm{C} / 18^{\circ} \mathrm{C}$ 区には，鉢内に温度コントロー ラー（TC-101，（株）イワキ）のセンサーを土壌面から深さ 約 $3 \mathrm{~cm}$ の位置に埋設し, 根域温度が設定温度になるよう
に水中ヒーターを制御した． $8^{\circ} \mathrm{C} /$ 無加温区抢よび $13^{\circ} \mathrm{C} /$ 無加温区の根域温度は調節せず, 他区と同様に給水ポンプ で水を循環させた。

根域温度と気温は温度ロガー（RTR-52A，(株)ティアン ドディ）を用い 10 分間隔で自動計測した。根域温度測定 用センサーは温度コントローラーのセンサーと同じ位置に 設置し, 気温測定用のセンサーは電気温風機のセンサーと 束ね, 鉢上面約 $10 \mathrm{~cm}$ の位置に設置した。

日平均気温拉よび日平均根域温度は 10 分間隔で記録さ れた温度データを平均して求めた。消費電力量はワット チェッカー（TAP-TST5, サンワサプライ(株)）で常時測 定した.

実験は 2 月 1 日から 4 月 22 日まで行った。開花株率は 小花が 1 輪以上開花している株数を供試株数で除して求 めた。 4 月 22 日から 23 日にかけて全株を葉, 茎抒よび花 に分けて採取した。葉面積は葉面積計（LI-3100, LI-COR, Inc）で計測した．各部位を $80^{\circ} \mathrm{C} て ゙$ 通風乾燥後に乾物重を 測定した，得られた結果は，Tukeyの多重検定により有意 差検定を行った.

\section{結果}

実験期間中の気温と根域温度の代表例として，厳冬期 （2014年2月 5 日～9 日）の日変化を第 1 図に示した．各 区の最低気温は，ほ涪設定ど打りに推移した。根域温度は $8^{\circ} \mathrm{C} /$ 無加温区では最低温度が約 $8^{\circ} \mathrm{C}$, 最高温度は約 $13^{\circ} \mathrm{C}$ で推移した. $13^{\circ} \mathrm{C} /$ 無加温区では $8^{\circ} \mathrm{C} /$ 無加温区よりも約 $2^{\circ} \mathrm{C}$ 高く推移した。根域を加温した $8^{\circ} \mathrm{C} / 13^{\circ} \mathrm{C}$ 区と $8^{\circ} \mathrm{C} /$ $18^{\circ} \mathrm{C}$ 区の最低温度は概衫設定ど沶りに推移し, 最高温度 は $8^{\circ} \mathrm{C} / 13^{\circ} \mathrm{C}$ 区では約 $17^{\circ} \mathrm{C}, 8^{\circ} \mathrm{C} / 18^{\circ} \mathrm{C}$ 区では $20^{\circ} \mathrm{C}$ を上 回った。な抢，2月 8 日は降雪のため，日中の温度上昇は 見られなかった。

第 2 図に実験期間中の日平均気温と日平均根域温度の推 移を示した。 日平均気温は最低気温 $8^{\circ} \mathrm{C}$ 設定の 3 区に扔い て, 2 月中旬の約 $12^{\circ} \mathrm{C}$ から 3 月下旬の約 $18^{\circ} \mathrm{C}$ 更徐々に 上昇し，3月下旬以降は $13^{\circ} \mathrm{C} /$ 無加温区とほとんど差がな くなった. $13^{\circ} \mathrm{C} /$ 無加温区の日平均気温は, 実験期間中 $15 \sim 18^{\circ} \mathrm{C}$ の間を推移した。 日平均根域温度は, $8^{\circ} \mathrm{C} /$ $18^{\circ} \mathrm{C}$ 区に扮いて実験期間中約 $19^{\circ} \mathrm{C}$ でほぼ一定に推移し た. $8^{\circ} \mathrm{C} / 13^{\circ} \mathrm{C}$ 区では 2 月中旬から 3 月上旬にかけて $14 \sim$ $15^{\circ} \mathrm{C}$ 前後であったが 3 月下旬には約 $17^{\circ} \mathrm{C}$ をで上昇した.

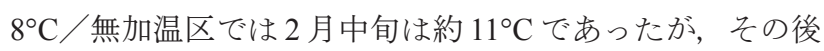
上昇し 3 月下旬には約 $17^{\circ} \mathrm{C}$ となった。 また, $13^{\circ} \mathrm{C} /$ 無加 温区では 3 月中旬までは $8^{\circ} \mathrm{C} /$ 無加温区よりも $1 \sim 2{ }^{\circ} \mathrm{C}$ 高 く推移したが，3月下旬以降には両者に活とんど差がなく なった。

第 1 表に実験期間中の電気温風機と根域加温用ヒータ一 の消費電力量を示した。電気温風機の消費電力量は $13^{\circ} \mathrm{C}$ ／無加温区で最も多くなり，最低気温を $8^{\circ} \mathrm{C}$ 亿設定した 3 区では根域温度の設定温度が高くなるほど減少した。根域 

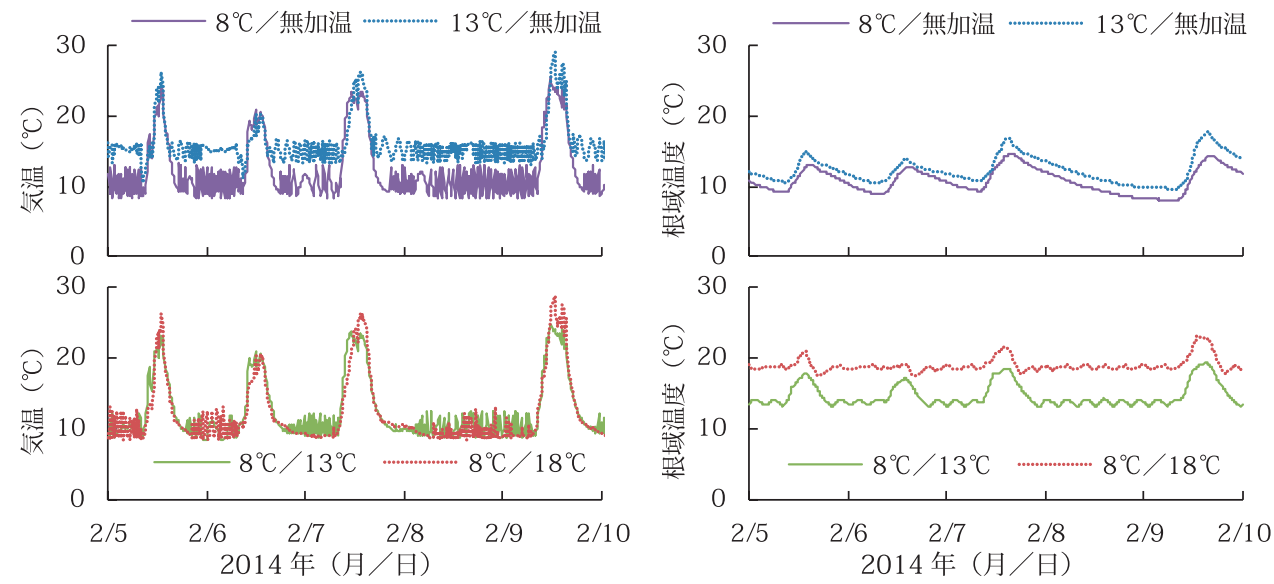

第 1 図 気温と根域温度の日変化（2014年 2 月 5 日〜 日 ) 各区の気温と根域温度は 10 分間隔で自動的に記録した
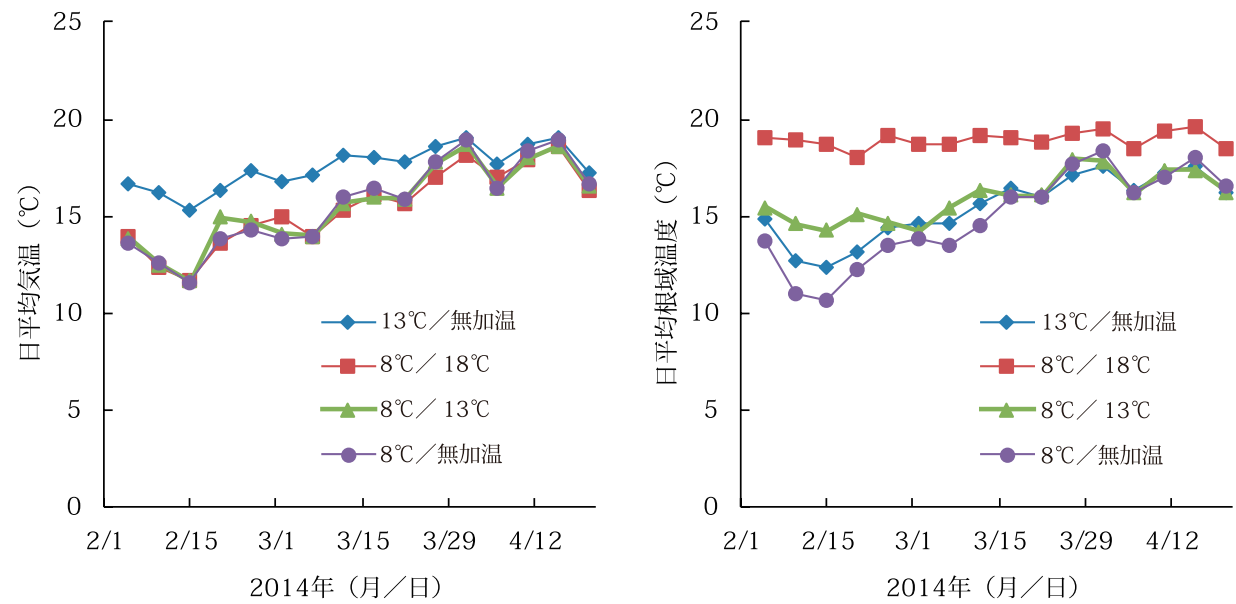

第 2 図 実験期間中の日平均気温と日平均根域温度の推移（5日ごとの平均） 10 分間隔で記録した温度データを平均して日平均気温と日平均根域温度を算出した

第 1 表 実験期間中の電気温風機と根域加温用ヒータ一の消 費電力量

\begin{tabular}{ccccc}
\hline \hline $\begin{array}{c}\text { 温度区 } \\
\begin{array}{c}\text { 最低気温 } \\
\text { 根域温 }\end{array}\end{array}$ & $\begin{array}{c}\text { 電気温風機 } \\
(\mathrm{kwh} / 区)\end{array}$ & $\begin{array}{c}\text { 根域加温用 } \\
\begin{array}{c}\text { ( } \\
(\mathrm{kwh} / 区\end{array}\end{array}$ & $\begin{array}{c}\text { 合計 } \\
(\mathrm{kwh} / 区)\end{array}$ & $\begin{array}{c}\text { 削減率 } \\
(\%)\end{array}$ \\
\hline $13^{\circ} \mathrm{C} /$ 無加温 & 925 & 0 & 925 & - \\
$8^{\circ} \mathrm{C} / 18^{\circ} \mathrm{C}$ & 103 & 523 & 626 & 32 \\
$8^{\circ} \mathrm{C} / 13^{\circ} \mathrm{C}$ & 148 & 213 & 361 & 61 \\
$8^{\circ} \mathrm{C} /$ 無加温 & 228 & 0 & 228 & 75 \\
\hline
\end{tabular}

${ }^{\mathrm{z}} 13^{\circ} \mathrm{C} /$ 無加温の消費電力量に対する削減率

加温用ヒーターの消費電力量は $8^{\circ} \mathrm{C} / 18^{\circ} \mathrm{C}$ 区では $523 \mathrm{kwh}$ /区， $8^{\circ} \mathrm{C} / 13^{\circ} \mathrm{C}$ 区では $213 \mathrm{kwh} /$ 区であった。合計の消 費電力量は $13^{\circ} \mathrm{C} /$ 無加温区で最も多く, 最低気温 $8^{\circ} \mathrm{C}$ 設 定では根域温度が高い注ど多くなった． $13^{\circ} \mathrm{C} /$ 無加温区 に対する消費電力量の削減率は, $8^{\circ} \mathrm{C} / 18^{\circ} \mathrm{C}$ 区で $32 \%$, $8^{\circ} \mathrm{C} / 13^{\circ} \mathrm{C}$ 区で $61 \% ， 8^{\circ} \mathrm{C} /$ 無加温区で $75 \%$ であった.

第 2 表にインパチェンスの生育と開花に及ぼす根域加温
第2 表 インパチェンスの生育と開花に及ぼす根域加温の影響

\begin{tabular}{crrrrr}
\hline \hline $\begin{array}{c}\text { 温度区 } \\
\text { 最低気温 } \\
\text { 根域温度 }\end{array}$ & $\begin{array}{c}\text { 葉数 } \\
\text { (枚 } / \text { 株) }\end{array}$ & $\begin{array}{c}\text { 葉面積 } \\
\left(\mathrm{cm}^{2} / \text { 株) }\right.\end{array}$ & $\begin{array}{c}\text { 分枝数 } \\
(\text { 本 } / \text { 株) }\end{array}$ & $\begin{array}{c}\text { 蕾数 } \\
(\text { 侏) }\end{array}$ & $\begin{array}{c}\text { 花数 } \\
(\text { 輪 } / \text { 株) }\end{array}$ \\
\hline $13^{\circ} \mathrm{C} /$ 無加温 & $106.7 \mathrm{~b}^{\mathrm{z}}$ & $127.9 \mathrm{~b}$ & $11.4 \mathrm{~b}$ & $23.5 \mathrm{~b}$ & $7.0 \mathrm{~b}$ \\
$8^{\circ} \mathrm{C} / 18^{\circ} \mathrm{C}$ & $186.5 \mathrm{a}$ & $346.1 \mathrm{a}$ & $18.3 \mathrm{a}$ & $43.0 \mathrm{a}$ & $14.7 \mathrm{a}$ \\
$8^{\circ} \mathrm{C} / 13^{\circ} \mathrm{C}$ & $103.7 \mathrm{~b}$ & $150.6 \mathrm{~b}$ & $9.8 \mathrm{~b}$ & $25.4 \mathrm{~b}$ & $7.7 \mathrm{~b}$ \\
$8^{\circ} \mathrm{C} /$ 無加温 & $91.2 \mathrm{~b}$ & $106.9 \mathrm{c}$ & $8.1 \mathrm{~b}$ & $22.1 \mathrm{~b}$ & $5.3 \mathrm{c}$ \\
\hline
\end{tabular}

${ }^{\mathrm{z}}$ Tukey の多重検定により異なる符号間に5\%の危険率で有 意差あり $(\mathrm{n}=5)$

の影響について示した。葉数は $8^{\circ} \mathrm{C} / 18^{\circ} \mathrm{C}$ 区で 186.5 枚と 最も多くなり, $13^{\circ} \mathrm{C} /$ 無加温区と $8^{\circ} \mathrm{C} / 13^{\circ} \mathrm{C}$ 区の $1.7 \sim 1.8$ 倍, $8^{\circ} \mathrm{C} /$ 無加温区の 2.0 倍に達した。葉面積は $8^{\circ} \mathrm{C} /$

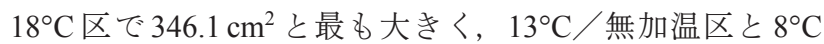
$/ 13^{\circ} \mathrm{C}$ 区の $2.3 \sim 2.7$ 倍, $8^{\circ} \mathrm{C} /$ 無加温区の約 3.2 倍となっ た. 分枝数は $8^{\circ} \mathrm{C} / 18^{\circ} \mathrm{C}$ 区で 18.3 本と最も多くなった. 蕾数は $8^{\circ} \mathrm{C} / 18^{\circ} \mathrm{C}$ 区で最も多く 43.0 個となり，そのほか 
第 3 表 インパチェンスの地上部の乾物重に及ぼす根域加温 の影響

\begin{tabular}{cllll}
\hline \hline $\begin{array}{c}\text { 温度区 } \\
\text { 最低気温 } \\
\text { 根域温 }\end{array}$ & $\begin{array}{c}\text { 葉 } \\
(\mathrm{g} / \text { 株 })\end{array}$ & $\begin{array}{c}\text { 茥 } \\
(\mathrm{g} / \text { 株 })\end{array}$ & $\begin{array}{l}\text { 花と蕾 } \\
(\mathrm{g} / \text { 株 })\end{array}$ & $\begin{array}{c}\text { 地上部の合計 } \\
(\mathrm{g} / \text { 株 })\end{array}$ \\
\hline $13^{\circ} \mathrm{C} /$ 無加温 & $0.31 \mathrm{bc}^{\mathrm{z}}$ & $0.19 \mathrm{bc}$ & $0.21 \mathrm{bc}$ & $0.71 \mathrm{bc}$ \\
$8^{\circ} \mathrm{C} / 18^{\circ} \mathrm{C}$ & $0.70 \mathrm{a}$ & $0.58 \mathrm{a}$ & $0.50 \mathrm{a}$ & $1.77 \mathrm{a}$ \\
$8^{\circ} \mathrm{C} / 13^{\circ} \mathrm{C}$ & $0.33 \mathrm{~b}$ & $0.23 \mathrm{~b}$ & $0.25 \mathrm{~b}$ & $0.81 \mathrm{~b}$ \\
$8^{\circ} \mathrm{C} /$ 無加温 & $0.24 \mathrm{c}$ & $0.15 \mathrm{c}$ & $0.16 \mathrm{c}$ & $0.55 \mathrm{c}$ \\
\hline
\end{tabular}

${ }^{\mathrm{z}}$ Tukey の多重検定により異なる符号間に5\%の危険率で有 意差あり $(n=5)$

の区では $22.1 \sim 25.4$ 個であった. 花数は $8^{\circ} \mathrm{C} / 18^{\circ} \mathrm{C}$ 区で 最も多く 14.7 輪, $13^{\circ} \mathrm{C} /$ 無加温区と $8{ }^{\circ} \mathrm{C} / 13^{\circ} \mathrm{C}$ 区は $7.0 \sim$ 7.7 輪で $8^{\circ} \mathrm{C} / 18^{\circ} \mathrm{C}$ 区の約半分であった. $8^{\circ} \mathrm{C} /$ 無加温区 は 5.3 輪と最も少なかった。

第 3 表にインパチェンスの地上部の乾物重に及ぼす根域 加温の影響について示した。葉, 茎拈よび花と蕾の乾物重 は $8^{\circ} \mathrm{C} / 18^{\circ} \mathrm{C}$ 区で最も多く, $8^{\circ} \mathrm{C} / 13^{\circ} \mathrm{C}$ 区, $13^{\circ} \mathrm{C} /$ 無加温 区， $8^{\circ} \mathrm{C} /$ 無加温区の順で少なくなった。地上部の合計の 乾物重は $8^{\circ} \mathrm{C} / 18^{\circ} \mathrm{C}$ 区で $1.77 \mathrm{~g}$ と最も多く, 気温と根域温 度が最も低い $8^{\circ} \mathrm{C} /$ 無加温区では $0.55 \mathrm{~g}$ と最も少なかった。

第 3 図にインパチェンスの開花株率の推移に及ぼす根域 加温の影響について示した。 3 月 11 日に $8^{\circ} \mathrm{C} / 18^{\circ} \mathrm{C}$ 区, $8^{\circ} \mathrm{C} / 13^{\circ} \mathrm{C}$ 区, $13^{\circ} \mathrm{C} /$ 無加温区で開花が認められた. $8^{\circ} \mathrm{C}$ $/ 18^{\circ} \mathrm{C}$ 区では開花が急速に進み 3 月中旬には $60 \%$ を超光, 4 月 1 日には $100 \%$ に達した. $8^{\circ} \mathrm{C} / 13^{\circ} \mathrm{C}$ 区の開花株率は 3 月中旬から急速に増加し，3月下旬には約 $90 \%$ まて達した. 開花株率が $80 \%$ に達した時期は根域加温を行った $8^{\circ} \mathrm{C} /$ $18^{\circ} \mathrm{C}$ 区と $8^{\circ} \mathrm{C} / 13^{\circ} \mathrm{C}$ 区では3 月中旬, 根域を加温しなかっ た $8^{\circ} \mathrm{C} /$ 無加温区と $13^{\circ} \mathrm{C} /$ 無加温区では 3 月末となり，根 域加温によって開花が約 10 日間早くなった。

第 4 図に実験終了時のインパチェンスの生育と開花状況

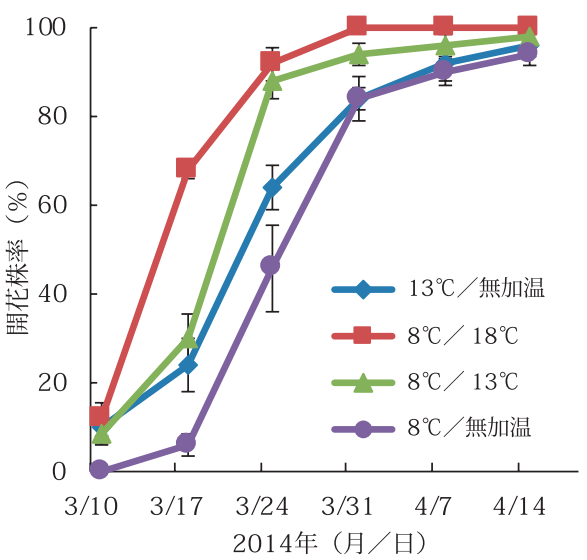

第3図インパチェンスの開花株率の推移に及ぼす根域加温 の影響

について示した. $8^{\circ} \mathrm{C} /$ 無加温区， $8^{\circ} \mathrm{C} / 13^{\circ} \mathrm{C}$ 区拈よび $13^{\circ} \mathrm{C} /$ 無加温区の株は小さかったが， $8^{\circ} \mathrm{C} / 18^{\circ} \mathrm{C}$ 区の草姿 は製品としてのボリューム感があり花数も多かった.

第 5 図に実験期間中の各区の平均根域温度および平均気 温と葉面積拈よび地上部の乾物重との間の相互関係につい て示した. 葉面積と地上部の乾物重は, 平均根域温度の上 昇に伴い直線的に増加し，両者の相関係数はそれぞれ $r=0.999$ および $r=0.998$ と $1 \%$ の危険率で有意性が認めら れた。一方，各区の平均気温と葉面積执よび地上部の乾物 重との間には相関関係は見られなかった.

\section{考察}

インパチェンスは花壇苗としての需要が多く，春の早期 出荷のためには冬季に播種し育苗する必要がある。インパ チェンスの生育適温は $20 \sim 25^{\circ} \mathrm{C}$ と高いため, 冬季の生産 では暖房コストがかかる，そこで，本研究ではいくつかの 品目で効果が示されている RECSによる根域加温（窪田 ら，2013）が冬季のインパチェンスの生育・開花に与光る

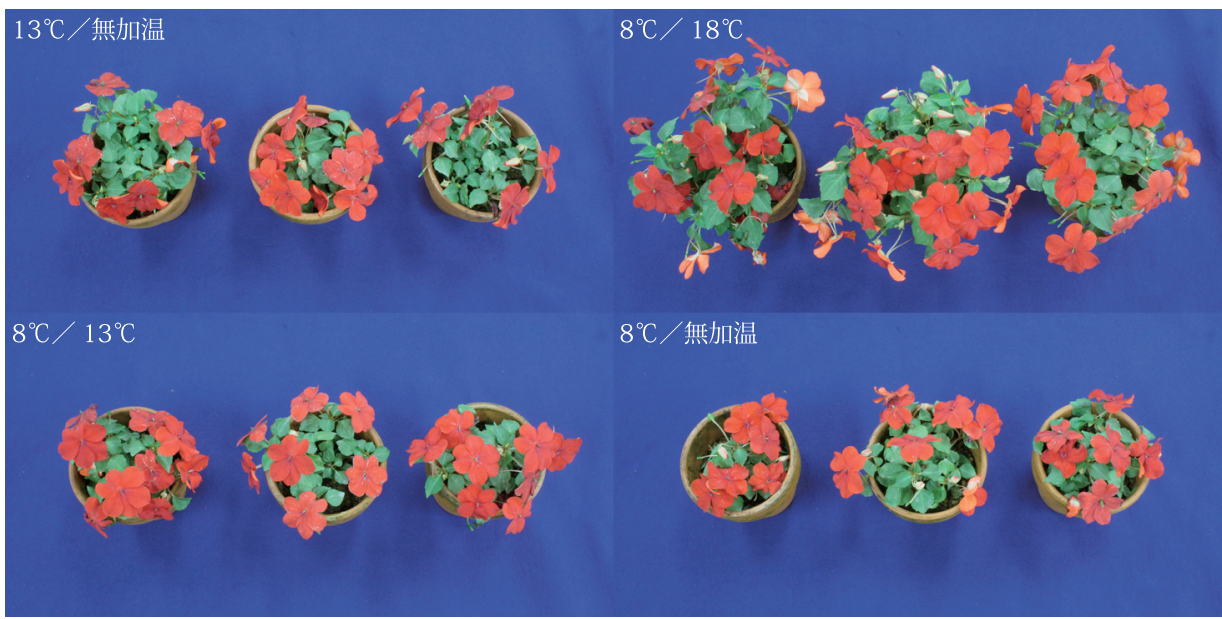

第 4 図インパチェンスの生育と開花に及ぼす根域加温の影響 2014 年 4 月 22 日撮影 

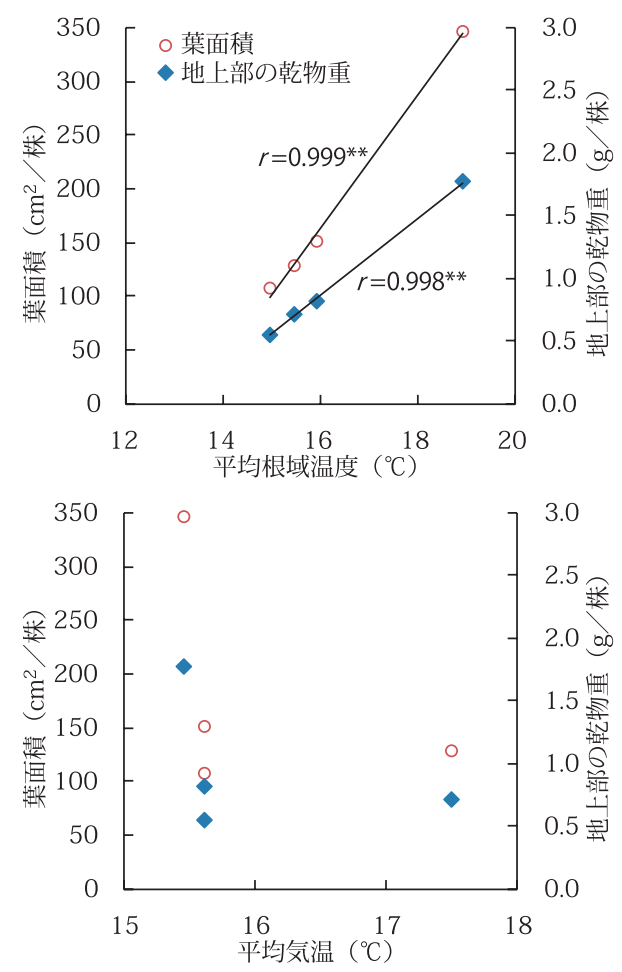

第 5 図 実験期間中の平均根域温度および平均気温と葉面積 扣よび地上部の乾物重との相互関係 **は1\%の危険率で有意性有りを示す

影響を検討するとともに，その省エネルギー性について評 価した。

RECSのプロトタイプを用いた本実験に打いて，インパ チェンスの生育と開花は最低気温を $13^{\circ} \mathrm{C}$ 設定とし根域を 加温しなかった $13^{\circ} \mathrm{C} /$ 無加温区ょりも, 最低気温を $8^{\circ} \mathrm{C}$ 設定とし根域を $18^{\circ} \mathrm{C}$ に加温した $8^{\circ} \mathrm{C} / 18^{\circ} \mathrm{C}$ 区で著しく促 進された（第 $2 ， 3$ 表，第 $3 ４$ 図). 電気温風機の消費電力 量は，最低気温を $8^{\circ} \mathrm{C}$ 設定とした区では根域温度が高くな るほど減少した（第1表）。ひは，根域加温によって鉢 土表面またはRECS の装置の一部から大気への熱供給が あったためと考えられる. 電気温風機と根域加温用ヒー タ一の合計消費電力量は, 生育と開花が最も促進された $8^{\circ} \mathrm{C} / 18^{\circ} \mathrm{C}$ 区に扔いて, $13^{\circ} \mathrm{C} /$ 無加温区よりも $32 \%$ 減少し た（第 1 表）。このことから，本実験で用いた RECS のプ ロトタイプは, 省エネルギー効果の高いシステムであると 考えられる.

葉面積および地上部の乾物重と各区の平均根域温度との 間には極めて高い相関関係が認められたが (第 5 図), 平 均気温との間には相関関係はほとんどなかった。このこと は，本実験の温度範囲内に打いてはインパチェンスの生育 に対して気温よりも根域温度が強い影響を与えていること を示唆している，現在まで，植物の生育・開花に最適な気 温については，極めて多くの検討がなされてきた．このら ち, 鉢物・苗物栽培では, 気温を変化させると根域温度も ほぼそれに追随して変化する（窪田ら，2011）ため, 地上
部と地下部の温度の影響については同じ温度に調節した場 合の生育・開花反応を観察していることになる，一方，本 実験では, 気温は $8^{\circ} \mathrm{C}$ と低くても, 根域を $13^{\circ} \mathrm{C} や 18^{\circ} \mathrm{C} に$ 加温すると生育が促進されたことから，今後，気温と根域 温度を切り分けて多くの植物の生育・開花を評価すること により，さらに効率的な温度管理方法を開発するための基 礎資料を得ることができると考えられる.

根域温度を $18^{\circ} \mathrm{C}$ に加温すると, 葉数の増加に伴い葉面 積が著しく拡大し (第 2 表), 乾物重も増加した（第 3 表）. 開花は根域加温することで早い段階から始まり，開花株率 が 80\%以上に達した時期は根域無加温の 2 区よりも 1 週間 以上早く，蕾数と花数が有意に多かった．窪田ら（2013） は，ゼラニウムとバーベナの生育に及ぼす根域温度の影響 を検討したところ，根域温度の上昇に伴い葉数の増加，葉 面積の拡大，開花の促進を認めた。 また， ミニシクラメン では夏季に根域を $20^{\circ} \mathrm{C}$ に冷却すると葉面積が小さくなり, 開花が促進されることが明らかとなっている（村松ら， 2015)。異なる植物を用いたこれらの実験から，根域温度 の上昇に伴い葉面積が増加するといら共通の現象が認めら れる。

Nagasuga ら（2011）がイネの乾物生産と水吸収に及ぼす 根域温度の影響について検討した結果では，純同化率と個 葉の光合成速度には根域温度の影響は全くなかったが，根 域温度を $14^{\circ} \mathrm{C}$ に低下させると葉面積が減少するため乾物 生産も減少することを明らかにしている。そして，葉面積 の減少は低根域温度による根の生育抑制を通した地上部へ の水供給の制限によってもたらされることを明らかにし た. Boyer（1970）は, 葉の水ポテンシャルの変化は葉の 相対成長速度と光合成速度の両方に影響するが，葉の相対 成長速度は光合成速度よりも水ポテンシャルの変化に対 して極めて鋭敏に反応し，葉の水ポテンシャルがわずかに 低下しても大きく低下することをダイズ，ヒマワリ，トウ モロコシを例として示している，これらのことから，本実 験のインパチェンスに括いても根域温度が根の成長に影響 を与え, 根からの水吸収によって葉面積がコントロールさ れていた可能性がある。 今後, 根域温度が根の成長と植物 の水ポテンシャルに与える影響について検討する必要が ある。

以上のことから，本実験で使用した小規模な RECS に抒 いて, 生育適温よりも低い最低気温 $8^{\circ} \mathrm{C}$ とても, 根域温 度を $18^{\circ} \mathrm{C}$ に保つことでインパチェンスの生育と開花が促 進され，最低気温を約 $13^{\circ} \mathrm{C}$ に保つ慣行に準じた栽培より も消費電力量を抑えることが可能であった。.しかし，現 在, 花壇苗の営利栽培に扎いては, 一般的に黒ポリポット が利用されており，本実験で供試した素焼鉢とは根域の熱 伝導率などが異なると考えられることから，実用性には課 題が残る。今後はより実用に近いRECS の開発と実際栽培 規模におけるエネルギー消費量についての比較および適応 品目の拡大などについて検討する. 


\section{摘 要}

冬季に加温を必要とするインパチェンスの生育・開花と エネルギー消費量に及ぼす根域加温の影響について検討し た。最低気温と根域温度をそれぞれ $13^{\circ} \mathrm{C} /$ 無加温, $8^{\circ} \mathrm{C} /$ 無加温, $8^{\circ} \mathrm{C} / 13^{\circ} \mathrm{C}, 8^{\circ} \mathrm{C} / 18^{\circ} \mathrm{C}$ 亿設定した 4 区を設け, 根域環境制御システム（RECS）を用いてインパチェンス を 2014 年 2 月 1 日から 4 月 22 日まで栽培した。葉数，葉 面積, 地上部の乾物重, 花数は $8^{\circ} \mathrm{C} / 18^{\circ} \mathrm{C}$ 区で最も多く なった。葉面積および地上部乾物重は平均根域温度が高く なる核ど増加し，生育と平均根域温度の間には極めて高い 相関関係が認められた. 開花時期は $13^{\circ} \mathrm{C} /$ 無加温区と比 べると， $8^{\circ} \mathrm{C} / 13^{\circ} \mathrm{C}$ 区と $8^{\circ} \mathrm{C} / 18^{\circ} \mathrm{C}$ 区に扣いて約 10 日間 促進された. 生育と開花が最も促進された $8^{\circ} \mathrm{C} / 18^{\circ} \mathrm{C}$ 区 の消費電力量は $13^{\circ} \mathrm{C} /$ 無加温区よりも32\%削減された.

\section{引用文献}

新井 聡・和田朋幸・大石一史. 2009. 観葉植物の暖房方 法之暖房費節減効果. 愛知農総試研報. 41: 85-92.

Boyer, J. S. 1970. Leaf enlargement and metabolic rates in corn, soybean, and sunflower at various leaf water potentials. Plant Physiol. 46: 233-235.

神奈川県農業技術センター。 2012. 省エネルギー高生産を
目指したバラ株元加温技術. p. 4-5.

準田 聡・遠藤路子・林 里紀・高橋博徳・村松嘉幸・腰 岡政二. 2013. 根域環境制御システムによる根域温度 調節はバーベナとゼラニウムの生育・開花に影響す る. 園学研. 12: 97-102.

宔田 聡・遠藤路子・堀本大雅・村松嘉幸・腰岡政二. 2011. 根域環境制御システムに抢ける多孔質鉢の利用 と機能. 園学研. 10: 461-466.

森山友幸・伏原 肇・奥 幸一郎. 2011。株元加温が促成 ナスの着果，収量，品質に及活す影響．園学研．10: 545-550.

村松嘉幸・河野寿紀・窪田 聡・腰岡政二．2015，高温期 の根域冷却によるミニシクラメンの生育・開花促進. 園学研. 14: 267-272.

Nagasuga, K., M. Murai-Hatano and T. Kuwagata. 2011. Effects of low root temperature on dry matter production and root water uptake in rice plants. Plant Prod. Sci. 14: 22-29.

西村元男. 1994. 生育と生理・生態（インパチェンス）. 農業技術大系花卉編 8. $1 \cdot 2$ 年草. p. 7-8. 農文協. 東京.

農林水産省．2008．施設園芸省エネルギー型栽培の推進方 向について.p. 4. 